УДК 821.161 .1

DOI: $10.17223 / 19986645 / 59 / 11$

\title{
Е.Г. Новикова
}

\section{Ф.М. ДОСТОЕВСКИЙ И СИБИРСКОЕ ОБЛАСТНИЧЕСТВО СТАТЬЯ ПЕРВАЯ ${ }^{1}$}

\begin{abstract}
Взаимоотношения Ф.М. Достоевского и сибиряков впервые осмысляются в специальном аспекте сибирского областничества; впервые введена в научный оборот и проанализирована незаконченная статья Н.И. Наумова «Из воспоминаний детства (по поводу кончины Ф.М. Достоевского)»; впервые поставлен вопрос о влиянии идей Достоевского и петрамевиев на формирование идеологии сибирского областничества. В работе описана общая картина контактов Достоевского, петрашевцев и сибирских областников и показана специфика восприятия творчества Достоевского областниками.

Ключевые слова: Ф.М. Достоевский, «Записки из Мертвого дома», Г.Н. Потанин, «Воспоминания», Н.М. Ядриниев, Н.И. Наумов, С.Ф. Дуров, петрашевиь, сибирское областничество, Сибирь.
\end{abstract}

В томском архиве сибирского писателя Николая Ивановича Наумова хранятся черновые наброски его статьи под названием «Из воспоминаний детства (по поводу кончины Ф.М. Достоевского)» [1], предположительно датируемой 1881-1882 гг.; статья не только не закончена (на том же листе Наумов начинает писать другое произведение - рассказ «В карауле»), но ее текст перечеркнут писателем. Так произведение, посвященное сибирским писателем Достоевскому, уже в оформлении содержит загадку незаконченности и отказа от первоначального творческого замысла.

Датировка статьи 1881-1882 гг., очевидно, обусловлена ее заглавием «по поводу кончины Ф.М. Достоевского», свидетельствующим о том, что на ее создание Наумова подвигло известие о смерти великого русского писателя. Однако при этом в статье изначально были заложены существенные хронологические неточности. Текст начинается следующим утверждением автора: «Мне было 8 лет, когда я услышал в первый раз фамилию Ф.М. Достоевского. Отец мой, незначительный чиновник, служил в городе Омске Западной Сибири» [1]. И далее следуют его «воспоминания детства» об Омском остроге и каторжниках. Но Н.И. Наумов родился в 1838 г. (в Тобольске); в 1843 г. его отец Иван Николаевич, действительно служивший чиновником, был переведен в Омск, где семья прожила до 1846 г. В этом году И.Н. Наумов был переведен в Томск на место советника Томского губернского правления [2. С. 130], именно в 1846 г. Н.И. Наумову и исполнилось 8 лет. И очевидно, что в омский период жизни Наумовых (1843-1846 гг.) сибирский мальчик вряд ли мог «услышать в первый раз

\footnotetext{
${ }^{1}$ Исследование выполнено при финансовой поддержке РФФИ в рамках научного проекта № 18-012-90020/18.
} 
фамилию Ф.М. Достоевского», который в эти годы, закончив в 1843 г. Инженерное училище, только начинал литературную деятельность (1846 г. - выход в свет его первого романа «Бедные люди»). Заключение Достоевского в Омском остроге - это 1850-1854 гг. (в это время Н.И. Наумов продолжает жить в Томске [2. С. 130]). Можно предположить, что осознание этих очевидных хронологических и историко-культурных несообразностей и заставило Наумова отказаться от первоначального замысла написать детские воспоминания о Достоевском в Омском остроге.

Этот незаконченный текст Наумова самым непосредственным образом соотносится с его опубликованными воспоминаниями. Воспоминания («автобиографию») Наумов создал по просьбе давнего друга, известного петербургского литературного критика А.М. Скабичевского, и первоначально они вошли в письмо к нему от 29 августа 1889 г. из Томска: «Ты просишь биографических сведений обо мне. Сообщу тебе их по возможности кратко. Родился я 16 мая 1838 года в городе Тобольске, как пишут в романах, от бедных, но благородных родителей» [3. С. 177].

Далее писатель следующим образом описывает омское детство: «Судьбе угодно было, чтобы с самого раннего детства я видел одни только печальные картины человеческих страданий. Дом наш в Омске выходил окнами на площадь перед крепостным валом. Летом обыкновенно с четырех утра на этой площади производили учение солдатам... и тут-то секли их и розгами, и палками, и шомполами от ружей. Далеко разносились крики истязаемых жертв. На этой же площади гоняли сквозь строй и солдат, и преступников. Я и теперь без содрогания не могу вспомнить этих сцен» [Там же. С. 178]. Текст об Омске в незаконченной статье о Достоевском, очевидно предшествующий письму к А.М. Скабичевскому по времени создания, представляет собой некий первоначальный вариант этих детских воспоминаний писателя, в одних фрагментах - более развернутый, в других - сокращенный: «Занимаемая нами квартира в одноэтажном деревянном доме выходила окнами на обширную площадь, оканчивающуюся небольшим земляным валом, каким окружена Омская крепость <..> Мимо дома ежедневно проходили небольшие партии так называемых крепостных арестантов, т.е. каторжных, содержащихся в остроге. С участием я привык уже видеть суровые заклейменные лица этих несчастных $<\ldots>$ И с детства бессознательно привык сочувствовать положению этих раздавленных жизнью людей. Летом, когда окна от квартиры были раскрыты, старик-отец всегда останавливал эти партии, и из них выходил какой-нибудь арестант, сопровожденный конвойным, подходил к окну, сняв шапку со своей до половины обритой головы, и принимал из рук отца подаяние. С каким любопытством и, вместе, страхом я всматривался из-за спины отца в эти бледные, жалкие, изможденные лица, нередко изуродованные клеймами, как чутко прислушивался к звуку их кандалов. Я знал, что вот это варнаки, прошедшие сквозь тысячи палок или, нередко, стеганные плетьми убийцы» [1].

По свидетельству Г.Н. Потанина, Наумов мог встречаться с Достоевским в Петербурге: «Милюков пригласил его (Наумова. - E.H.) на свои 
вечера, которые были многолюдны и оживлялись иногда горячими диспутами, например, Антоновича с Достоевским» [4. С. 131]. Тем не менее именно представление о Достоевском как о каторжнике Омского острога стало для Наумова отправной точкой для создания воспоминаний о нем, пусть в данном случае неточных. Но в такой его изначальной творческой установке проявились сущностные особенности восприятия Достоевского сибирским областничеством, к которому Наумов был крайне близок.

Начиная с 1859 г. в Петербурге оформляется «сибирское землячество», основные участники которого (Г.Н. Потанин, Н.М. Ядринцев, Н.С. Щукин и др.) станут лидерами сибирского областничества [5]. Потанин и Ядринцев изменили судьбу Наумова, вызвав его из Сибири в Петербург. Ядринцев и Наумов были знакомы с детства, они вместе учились в Томской гимназии. Из «Воспоминаний» Потанина: «Выехав в Петербург, Ядринцев рассказал мне, что у него в Сибири есть друг <.. > и что он уже напечатал один рассказ «У перевоза». Оба мы думали, что его нужно вызвать в столицу. Я написал письмо Наумову, служившему тогда в Томске, убеждая его бросить службу и поступить в университет. Письмо мое подействовало» [6. С. 116]. Благодаря этому Наумов приобщился к университетскому образованию и к столичной журналистике, в результате чего стал, по мнению Потанина, первым истинно сибирским писателем: «Рассказами Наумова начинается сибирская беллетристика, и мы горячо приветствуем это начало. Твердо надеемся, что пример Н.И. Наумова не останется без подражания и в среде его земляков найдутся продолжатели дела, которому он положил начало» [4. С. 236-237].

О творчестве Наумова как о «начале сибирской беллетристики» Потанин пишет в своей программной статье «Сибирские повести и рассказы» (1876), в которой ставит вопрос о сибирской литературе - и о литературе о Сибири. Эта работа Потанина демонстрирует ключевые ценностные подходы сибирского областничества к художественной литературе: ее темой должна быть Сибирь. В свою очередь, специфика незаконченного текста Наумова определялась тем, что в нем имя и образ Достоевского вписаны исключительно в сибирский контекст «тюрьмы и ссылки» [7], связанный в том числе и с личным жизненным опытом сибиряка. Именно так и только так воспринимали великого русского писателя сибирские областники, и для них это не была некая ошибка или некое заблуждение, но - принципиальная позиция.

Наиболее ярко это проявилось в творчестве Ядринцева, который называл себя «последователем Достоевского» и «собратом по духу и судьбе» [8. С. 58-59]. В круге сибирского областничества Ядринцев был одним из лучших журналистов и, бесспорно, ведущим литературным критиком. «Трудно переоценить значение Н.М. Ядринцева для развития литературы Сибири <..> Литература и искусство никогда не имели для Ядринцева самодовлеющего значения - они были тесно связаны с проблемами общественного развития Сибири», - подчеркивает Ю.С. Постнов в своей работе «Н.М. Ядринцев - литературовед и критик» [Там же. С. 7]. Показательны 
сами названия его литературно-критических статей: «Сибирь перед судом русской литературы», «Сибирь на похоронах Тургенева», «М.И. Орфанов и его пребывание в Сибири», «Судьба сибирской поэзии и старинные поэты Сибири», «Н.В. Гоголь и его областное значение»... Специальное обращение к творческому наследию Достоевского - дважды: в статьях «Преступники по изображению романтической и натуральной школы» (1872) и «Достоевский в Сибири» (1897).

Уже в начале петербургского литературного пути Ядринцев связывал с Достоевским особые надежды. Потанин в «Воспоминаниях» продолжает: «Наумов уже печатался и вращался в литературном кругу, а Ядринцев в этом отношении отстал от него $<\ldots>$ Несколько времени спустя Ядринцев сам надумал тему для статьи» [6. С. 117] - критический разбор книги И.И. Завалишина «Описание Западной Сибири» [9]. И, как вспоминает Потанин, первым журналом, в который Ядринцев отнес свою статью, стало «Время» братьев Ф.М. и М.М. Достоевских: «...мы были в восторге от этого бойкого пера и благословили его нести рукопись в редакцию. Он снес ее в журнал «Время»; но статью не приняли, сказали, что он на муху пошел с обухом, что книжка имеет ничтожное значение и жаль на нее тратить в журнале целый десяток страниц» [6. С. 118]. Коллизия эта достаточно показательна: с одной стороны, областники «благословляют» публикацию статьи, посвященной сибирской проблематике, в журнале, позицию которого они продолжают связывать с Сибирью; с другой стороны, редакция журнала посчитала, что книга о Сибири «имеет ничтожное значение»; Достоевский в это время в своих журналах «Время» и «Эпоха» уже ставил иные - почвеннические - задачи. Вероятно, этим отказом можно объяснить и то, что небольшие воспоминания Ядринцева о «литературном кружке Достоевских» [8. С. 31], вошедшие в его статью «Чокан Чингисович Валиханов» (1866), носят сугубо критический характер: «В Петербурге он (Валиханов. - E.H.) тоже не был особенно счастлив в своих знакомствах. Сойдясь с литературным кружком Достоевских, он не мог много заимствовать от него и сделаться серьезным тружеником науки. В этом кружке он познакомился с поэтом Всеволодом Крестовским <..> квазиобразованные писатели, подобные Вс. Крестовскому, потакали страстям молодого инородца, с которыми он сходился, ища в них цивилизованных людей, а находил людей, проводивших в поэтической форме разврат» [Там же]. На фоне известных взаимоотношений Чокана Валиханова с Достоевским данное высказывание выглядит вполне субъективным.

Еще одним возможным объяснением этого достаточно резкого описания Ядринцевым редакции журналов Достоевских может быть то, что в центре его - не Достоевские и даже не Чокан Валиханов, но В.В. Крестовский, положение которого в редакции журналов братьев Достоевских - это «картина непростых и меняющихся взаимоотношений» [10. С. 109]. Именно в период расцвета «кружка Достоевских» 1862-1863 гг. он начинает писать свой самый известный роман «Петербургские трущобы» (18641866), отрывки из которого были опубликованы в том числе и в журнале 
«Эпоха» за 1864 г. «Замысел «Петербургских трущоб» рождался и оформлялся при несомненном творческом взаимодействии автора с двумя близкими ему в этот период писателями: Достоевским и Помяловским», - указывает В.А. Викторович [10. С. 103].

Но мнение Ядринцева по поводу соотношения творчества Достоевского и В.В. Крестовского было иным, что проявилось в статье «Преступники по изображению романтической и натуральной школы», первой из двух его литературно-критических работ, связанных с Достоевским. Статья Ядринцева начинается размышлением о том, что «в последнее десятилетие в русской беллетристике и этнографии все чаще и чаще встречаются описания вообще мира преступников, а также исследования над отдельной личностью преступника» [8. С. 32]; обзор и анализ этой литературы определил общее содержание работы. Позиция автора задана в названии: с точки зрения Ядринцева, в русской литературе сформировано два прямо противоположных подхода к описанию мира «тюрьмы и ссылки», подход «романтический» и «натуральный» (реалистический). По этому основанию он и противопоставляет «Петербургские трущобы» В.В. Крестовского и «Записки из Мертвого дома» Достоевского.

В романе В.В. Крестовского «что ни страница, то фальшь и недобросовестность в изображении преступников <..> Для усугубления эффекта являются невинные жертвы преступления, которые сводятся в могилу, тогда как преступники отправляются в Сибирь «с изиническими песнями». Оставляя в стороне лубочную живопись, характеризующую это произведение, мы укажем только на заключающуюся в нем клевету на жизнь и человеческую природу <..> при всевозможной испорченности человека всегда можно найти в его характере черты вполне симпатичные, вполне человеческие» [Там же. С. 40].

Последнее утверждение для Ядринцева принципиально; истинный «реализм» в изображении преступников, с его точки зрения, «прежде всего требует верного и близкого изображения жизни» [Там же. С. 49]. Таким представлениям автора о глубоко реалистическом изображении личности преступника и преступного мира полностью отвечают «Записки из Мертвого дома», это произведение «выражает вполне человечный и сострадательный взгляд на положение преступника и по правдивости своей принадлежит к лучшим произведениям натуральной школы» [Там же. С. 42]. В качестве примера Ядринцев приводит описание Орлова, и выраженное в нем авторское отношение к преступнику близко сибирскому областнику: «Достоевский рассказывает, что когда он или кто другой начинал расспрашивать <..> преступника Орлова и подбираться к его совести, то тот смотрел на вопрошавшего как на дурака или маленького мальчика, над которым нельзя было не расхохотаться, и действительно он хохотал от души ${ }^{1}$. В самом деле, как будто совесть человека есть таба-

\footnotetext{
1 «Когда же понял, что я добираюсь до его совести и добиваюсь в нем хоть какогонибудь раскаяния, то взглянул на меня до того презрительно и высокомерно, как будто я
} 
керка, которую носят в кармане и предлагают понюхать из неё всякому желающему» [8. С. 45].

Но высокую оценку в статье заслужили только «Записки из Мертвого дома». Роман «Преступление и наказание», наоборот, по мнению Ядринцева, «написан под влиянием иных чувств и воззрений; он характеризует одну злую сторону человеческого характера, одни отвратительные черты, на которые преимущественно и налег художник, поэтому произведение его вышло крайне ненатурально и фальшиво» [Там же. С. 42]; «искусственностью проникнут весь роман «Преступление и наказание» г. Достоевского» [Там же. С. 44]. Подобное восприятие романа Достоевского могло быть обусловлено полным несогласием Ядринцева с идеями и положениями современной ему русской религиозной философии: «”Моя религия" < ..> Все русское общество уже увлечено этой философией <...> это не наша философия, начиная с Гоголя, кончая Достоевским» [Там же. С. 277]. Возможно, поэтому Ядринцев смог увидеть и прочитать здесь только «одну злую сторону человеческого характера, одни отвратительные черты» - ту позицию отношения к преступнику, против которой сибирский областник искренне протестовал.

Подход к Достоевскому только как к создателю «Записок из Мертвого дома» определяет и специально посвященную ему статью «Достоевский в Сибири». «Мертвый дом» - «самое великое и лучшее произведение Достоевского» [Там же. С. 65]. Статью отличает обильное цитирование фрагментов из «Мертвого дома», см.: [8. С. 60-62, 64-65; 11. Т. 4. С. 9-10, 22, 77, 231]; прием, следует отметить, для других работ Ядринцева совершенно нехарактерный. Более того, именно «Записки из Мертвого дома» воспринимаются как основа всего остального творчества писателя: «Впечатление, полученное в тюрьме и на каторге, до того было сильно, что Достоевский никогда не забывал этого мира несчастных и всегда обращался к нему в романах, поветях и «Дневнике писателя», и это были лучшие, наиболее прочувственные страницы» [8. С. 63]. Пожалуй, здесь сформулирована суть отношения сибирского областничества к творчеству Достоевского. Показательно, что эту позицию областников разделял современный сибирский ученый В.П. Владимирцев: «“Записки из Мертвого дома” можно по праву назвать книгой века. Если бы Достоевский оставил после себя лишь одни «Записки из Мертвого дома», он и тогда вошел бы в историю русской и мировой литературы» [12. С. 240]; это заставляет обратиться к вопросу о действительном значении «Записок из Мертвого дома» в творчестве Достоевского.

Начинается статья Ядринцева, подобно незавершенному тексту Наумова, описанием Омска, Омского острога: «На окраине русской земли, в отдаленной и забытой Сибири, на границе Киргизской степи стоит неболь- 
шой уездный город Омск <..> В нем находится старая упраздненная крепость с осыпавшимися валами $<\ldots>$ Здесь когда-то провел несколько лет тяжкой жизни Ф.М. Достоевский» [8. С. 58]. Ключевым ее моментом стало описание личной встречи Ядринцева с Достоевским в 1876 г.: «Когда я в 1876 году имел случай познакомиться с Федором Михайловичем Достоевским в Петербурге и сообщил, что я видел прежнюю его тюрьму, он, внезапно погруженный в воспоминания, спросил: «Ну, а где же теперь они-то, что сидели там?» (Он разумел каторжных.) Что мне было сказать? Прошло двадцать лет <..> «Да, ведь их не может существовать уже», - спохватился Федор Михайлович. Но я понял, что он внутренне был связан с их жизнью и судьбою» [Там же. С. 63]. Так проблематика «Достоевский в Сибири» постоянно уточняется как «Достоевский на каторге».

Пафос этой статьи сибирского критика - вновь пропаганда такого «реализма» в изображении преступников, в основе которого «человеколюбие, любовь и милосердие», поскольку «при глубоком наблюдении правда жизни ярче раскрывается» [Там же. С. 65]. Самым ярким примером этого опять стала позиция Достоевского: «Недаром Ф.М. Достоевский, испытавший знакомство со старым русским острогом, воскликнул в конце своих наблюдений: “Сколько в этих стенах погребено молодости! Сколько великих сил погибло здесь даром! Ведь надо уж все сказать: ведь этот народ необыкновенный был народ. Ведь это, быть может, и есть самый даровитый, самый сильный народ из всего народа нашего"1 » [7. С. 64]. Отношение Достоевского к преступнику, связанное с его почвенничеством, было для сибирского областника образцовым, что позволяет поставить специальный вопрос об определенном влиянии «Записок из Мертвого дома» на формирование позиции сибирского областничества.

С позицией Ядринцева об особом значении «Записок из Мертвого дома» Достоевского для современной России был полностью согласен Потанин. Более того, «Воспоминания» Потанина свидетельствуют о том, что петрашевцы вообще сыграли существенную роль в самом становлении сибирского областничества. Потанин был бесспорным духовным лидером областничества; не случайно во время следствия именно он взял на себя всю вину за сибирский «сепаратизм» и после суда был подвергнут процедуре гражданской казни [6. С. 205, 224-225; 13. С. 76-78]. Потанин вспоминает о том, что именно знакомство с петрашевцами, их рассказ о смертной казни и их политические взгляды привели к сущностной «метаморфозе» [6. С. 119] всего его мировоззрения в целом.

Достоевский был отправлен на каторгу вместе с С.Ф. Дуровым, с ним вместе он отбывал наказание и в Омском остроге. Они познакомились в кружке М.В. Буташевича-Петрашевского и, как вспоминает С.Д. Яновский,

\footnotetext{
${ }^{1}$ «И сколько в этих стенах погребено напрасно молодости, сколько великих сил погибло здесь даром! Ведь надо уже всё сказать: ведь этот народ необыкновенный был народ. Ведь это, может быть, и есть самый даровитый, самый сильный народ из всего народа нашего» [11. Т. 4. С. 231].
} 
«Федор Михайлович, разговаривая со мною о лицах, составляющих кружок Петрашевского, любил с особенным сочувствием отзываться о Дурове, называя его постоянно человеком очень умным и с убеждениями» [14. T. 1. С. 248]. Достоевский и Дуров оказались связаны одной судьбой. Они рядом стояли на эшафоте и, вместе с А.Н. Плещеевым, были «во второй очереди» на казнь. Из письма Достоевского брату Михаилу, написанному вечером 22 декабря 1849 г.: «Сегодня 22 декабря нас отвезли на Семеновский плац. Там всем нам прочли смертный приговор, дали приложиться к кресту, переломили над головой шпаги и устроили наш предсмертный туалет (белые рубахи). Затем троих поставили к столбу для исполнения казни. Я стоял шестым, вызывали по трое, след <овательно>, я был во второй очереди и жить мне оставалось не более минуты <..> Я успел тоже обнять Плещеева, Дурова, которые были возле, и проститься с ними» [11. Т. 28, С. 161-162]. Воспоминание о последней встрече братьев перед отправкой в Сибирь: «Помнишь ли, как мы расстались с тобой, милый мой, дорогой, возлюбленный мой? Только что ты оставил меня, нас повели, Дурова, Ястжембского и меня, заковывать» [Там же. С. 167].

Когда в Тобольске петрашевцев встретили жены декабристов Ж.А. Муравьева, П.Е. Анненкова с дочерью О.И. Ивановой и Н.Д. Фонвизина, последняя назвала Дурова своим племянником и, благодаря этому, поддерживала постоянную связь с ним и с Достоевским в течение всего пребывания их в Омском остроге. Как полагают современные исследователи, «Наталья Дмитриевна была чуть ли не единственным человеком, который писал Достоевскому во время пребывания его на каторге» [15. С. 79], Достоевскому и Дурову, о чем свидетельствует, в частности, одно из писем к ней Достоевского: «Последний раз, как я писал Вам <..> Я читал все Ваши адрессы (так у Достоевского. - E.H.) в письме к С <ергею> Д <урову> и возьму их на всякий случай» [11. Т. 28, С. 175]. Первое время после освобождения из острога Достоевский и Дуров, вновь вместе, жили в доме К.И. Иванова и О.И. Ивановой, дочери П.Е. Анненковой. Об этом вспоминает писатель в письме к П.Е. Анненковой от 18 октября 1955 г. из Семипалатинска: «С самого приезда моего в Семипалатинск я не получал почти никаких известий о Константине Ивановиче и многоуважаемой Ольге Ивановне <..> Полтора года назад, когда я и Дуров вышли с каторги, мы проведи почти целый месяц в их доме» [Там же. С. 195-196].

Но после этого их пути разошлись: Достоевский был зачислен рядовым в первую роту Сибирского 7-го линейного батальона и отправлен в Семипалатинск; Дуров сначала, также рядовым, был направлен в линейный батальон в Петропавловске, но почти сразу же вернулся Омск. Из того же письма Достоевского П.Е. Анненковой: «Вы, вероятно, уже знаете, что Дуров по слабости здоровья выпущен из военной службы и поступил в гражданскую, в Омске» [Там же. С. 196].

Дуров прожил в Омске с 1855 по 1857 г., когда ему было разрешено покинуть Сибирь. В это время с ним и познакомился Потанин, и эта встреча полностью «перевернула взгляды» на жизнь молодого сибирского казака: 
«...тут я в первый раз узнал, что существует особая порода людей, которых в Сибири называют «политики». До свидания с Дуровым я обожал императора Николая I <..> Я увидел в нем человека, всем своим существом протестовавшим против николаевского режима $<\ldots>$ Дуров в один вечер совершил со мной метаморфозу: его речи были оглушительны, потому что происходили от человека, глубоко пострадавшего от николаевского режима. Мои взгляды совершенно перевернулись не только на Николая I, но и вообще на монархизм» [6. С. 119-120]. Рожденный и воспитанный в среде сибирского казачества, окончивший Сибирский кадетский корпус и прослуживший уже в чине хорунжего и командира казачьей сотни, «обожавший императора» Потанин был «оглушен речами» и рассказами петрашевца.

В частности, на Потанина большое впечатление произвела история Н.П. Григорьева, рассказанная Дуровым. Вот она - в передаче Потанина: «Он мне рассказал историю Григорьева, своего товарища по несчастью. Григорьев в числе петрашевцев был приговорен к расстрелянию. Он стоял с завязанными глазами перед взводом с направленными на него ружьями, и в это время завязка спала с его глаз. Он увидел, что солдаты, которые должны были покончить с ними, взяты из его роты, и между ними фельдфебель, которого он очень любил; любимый человек должен был отдать приказ палить. Приговор к смертной казни не был исполнен над петрашевцами. Григорьев, как и другие, объявленные главными виновниками, был отправлен в Сибирь на каторгу, но он был привезен туда помешанным. Картина, которую он увидел, когда спала с его глаз повязка, так на него подействовала, что он моментально сошел с ума. Когда ему было разрешено выехать в Россию, Дуров увиделся с ним в Омске; Григорьев прожил в квартире сутки или более. Дуров рассказывал мне, что Григорьев был помешан на мести Николаю» [Там же. С. 119].

Действительно, Григорьев был одним из трех петрашевцев, вместе с М.В. Петрашевским и Н.А. Момбелли, которые стояли перед солдатами с наведенными на них ружьями; из воспоминаний петрашевца Ф.Н. Львова (написанных под редакцией М.В. Петрашевского): «Петрашевского, Момбелли и Григорьева повели, привязали к столбам и завязали глаза» [16. С. 58].

«С завязанными глазами» - это исторически достаточно неясная ситуация: в некоторых источниках утверждается, что Петрашевский, стоя перед взводом солдат, снял с себя смертный колпак: однако мог ли он это сделать с привязанными к столбу руками. В этом смысле «Воспоминания» Потанина интересны тем, что в них «завязка спала с его глаз» сама, но это был не Петрашевский, а Григорьев (хотя, конечно, на них как на смертниках были не простые «завязки»). При этом история об увиденной Григорьевым перед собой собственной роте и любимом фельдфебеле, хотя бы отчасти, но подтверждается из другого источника. Молодой барон А.Е. Врангель, учившийся в это время в Александровском лицее, выпускниками которого были Петрашевский, Н.А. Спешнев и другие петрашевцы (и позже в Семипалатинске ставший близким другом Достоевского), вспоминает о дне их казни: «В это время вошёл мой дядя Владимир Ермолае- 
вич Врангель, младший брат отца, служивший в конно-гренадерах, и объяснил мне, что < .. > везут на Семёновский плац петрашевцев, приговорённых к смертной казни, и что он пришёл со своим эскадроном из Петергофа, так как один из офицеров эскадрона, Григорьев, замешанный в деле Петрашевского, также должен быть казнён» [17. С. 20]. В 1849 г. Григорьев был отправлен в Нерчинскую каторгу, где его психическое заболевание обострилось, в 1856 г. был выпущен на поселение, в 1857 г. - отправлен под надзор семьи в Нижнем Новгороде как неизлечимо больной человек. Поэтому рассказ о личной встрече Дурова и Григорьева в Омске, которая могла состояться в 1856-1857 гг., также вызывает определенные вопросы.

Тем не менее на фоне этих продолжающихся исторических изысканий важнее всего тот контекст, в который помещен рассказ о петрашевцах Дурове и Григорьеве в «Воспоминаниях» Потанина: «...сибирское движение, которым уже веяло в воздухе» [5. С. 119].

Насколько нам известно, история сохранила две личные встречи Потанина с самим Достоевским. Они достаточно разные, но, представляется, их объединяет один общий «азиатский» колорит и смысл. В этом контексте Сибирь Достоевского начинает уточняться не только как «тюрьма и ссылка», но и как «Азия» [18]. Собственно говоря, это уже было обозначено, так или иначе, у Наумова и Ядринцева: «...какая-нибудь одинокая нора байгуш киргиза» [1], «...на окраине русской земли, в отдаленной и забытой Сибири, на границе Киргизской степи стоит небольшой уездный город Омск» [8. С. 58]... Первая зафиксированная встреча Потанина с Достоевским состоялась в Семипалатинске в 1856 г., вторая - в Петербурге в 1860 г. «Воспоминания» Потанина: «В Семипалатинске я встретился с Достоевским, но только на минуту; я входил в двери, а он выходил. Я остановился по одну сторону дверей, чтобы дать ему дорогу, он, оставаясь по другую сторону, предлагал мне первому перешагнуть порог. Произошло препирательство. Наконец он, улыбаясь, сказал: «Десять тысяч китайских церемоний!» Вот и все, что я от него услышал» [6. С. 63]. Такая вот забавная ситуация, которую можно было бы назвать «гоголевской», но Достоевский в Сибири ее квалифицирует как «китайские церемонии». Гораздо позже, в 1873 г., «китайским церемониям» у него будет посвящено целое вступление к «Дневнику писателя» [19].

В 1860 г. «Валиханов выступает в Русском географическом обществе с лекцией о Кашгарии <..> Среди слушателей находились Достоевский и друзья Валиханова - Потанин и Ядринцев» [20. Т. 1. С. 293]. В 18581959 гг. Чокан Валиханов совершил свою знаменитую экспедицию в Кашгарию - великое и таинственное место Туркестана, о чем и был сделан доклад на заседании Русского географического общества. Достоевский в контексте научных исследований Сибири и Азии, особая роль Чокана Валиханова как посредника между Достоевским и областниками - это важные темы, которые требуют специального изучения.

В данной же статье была сделана попытка описать общую картину знакомства и контактов Достоевского, петрашевцев и сибирских областников, 
была показана специфика восприятия творчества Достоевского областниками и поставлен вопрос о влиянии близких ему идей на формирование идеологии сибирского областничества. Личные встречи Потанина, Ядринцева и Наумова с Достоевским были немногочисленными, но труды областников свидетельствуют о том, что опыт смертной казни и каторги Достоевского, его почвенничество и политические взгляды петрашевцев сыграли существенную роль в формировании сибирского областничества.

\section{Лuтература}

1. Томский государственный университет. Научная библиотека. Отдел рукописей и книжных памятников. Архивный фонд. Вып. 7: Николай Иванович Наумов. Опись архива. Томск, 2008. № 14.

2. Новикова Е.Г. Томск в жизни Н.И. Наумова: эскизы без теней // Русские писатели в Томске. Томск, 1996. С. 128-146.

3. Автобиография Н.И. Наумова // Сибирские огни. 1963. № 9. С. 177-180 / публ. и примеч. И.Г. Попова.

4. Литературное наследство Сибири / сост. Н.Н. Яновский. Новосибирск : Зап.Сиб. кн. изд-во, 1986. Т. 7.

5. Дело об отделении Сибири от России / публ. А.Т. Топчия, Р.А. Топчия; сост. Н.В. Серебренников. Томск : Изд-во Том. ун-та, 2002.

6. Литературное наследство Сибири / сост. Н.Н. Яновский. Новосибирск : Зап.Сиб. кн. изд-во, 1983. Т. 6.

7. Ядринцев Н. М. Русская община в тюрьме и ссылке. СПб., 1872.

8. Литературное наследство Сибири / сост. Н.Н. Яновский. Новосибирск : Зап.Сиб. кн. изд-во, 1980. Т. 5.

9. Завалишин И.И. Описание Западной Сибири : в 3 т. М., 1862-1865.

10. Викторович В.А. Достоевский и Вс. Крестовский // Достоевский: Материалы и исследования. Л., 1991. Т. 9. С. 92-116.

11. Достоевский Ф.М. Полное собрание сочинений : в 30 т. Л. : Наука, 1972-1990.

12. Владимирцев В.П. Достоевский народный. Ф.М. Достоевский и русская этнологическая культура. Иркутск, 2007.

13. Обручев B.A. Григорий Николаевич Потанин: Жизнь и деятельность. М. ; Л. : Изд-во АН СССР, 1947 (Академия наук Союза ССР. Научно-популярная серия).

14. Яновский С.Д. Воспоминания о Достоевском // Ф.М. Достоевский в воспоминаниях современников: в 2 т. / вступ. ст., сост. и коммент. К.И. Тюнькина. М., 1990.

15. Громыко М.М. Сибирские знакомые и друзья Ф.М. Достоевского. 1850-1854 / отв. ред. Н.Н. Покровский. Новосибирск : Наука, 1985.

16. Львов Ф.Н., Буташевич-Петрашевский М.В. [Записка о деле петрашевцев] // Первые русские социалисты: Воспоминания участников кружков петрашевцев в Петербурге. Л., 1984.

17. Врангель А.Е., бар. Воспоминания о Ф.М. Достоевском в Сибири 1854-56 гг. СПб., 1912.

18. Новикова Е.Г. Г.Н. Потанин в Томске: филология, Сибирь, Восток и христианство // Вестник Томского государственного университета: Гуманитарный специальный выпуск. 1998. Т. 266. С. 27-33.

19. Алексеев П.В. «Китайское» вступление к «Дневнику писателя» Ф.М. Достоевского // Вестник Томского государственного университета. Филология. 2017. № 49. C. $98-112$.

20. Летопись жизни и творчества Ф.М. Достоевского : в 3 т. СПб. : Академический проект, 1993. 


\section{Fyodor Dostoevsky and Siberian Regionalism. Article One}

Vestnik Tomskogo gosudarstvennogo universiteta. Filologiya - Tomsk State University Journal of Philology. 2019. 59. 185-197. DOI: 10.17223/19986645/59/11

Elena G. Novikova, Tomsk State University (Tomsk, Russian Federation). E-mail: elennov@mail.ru

Keywords: F.M. Dostoevsky, The House of the Dead, G.N. Potanin, Memoirs, N.M. Yadrintsev, N.I. Naumov, S.F. Durov, the Petrashevtsy, Siberian regionalism (oblastnichestvo), Siberia.

In the article, the relations of Fyodor Dostoevsky and the Siberians are in focus in terms of Siberian regionalism (oblasthichestvo); the unfinished article "From Childhood Memories (On the Death of Fyodor Dostoevsky)" by Nikolay I. Naumov is first introduced into scientific discourse; the issue of the impact of Dostovesky's views and the Petrashevtsy ideas on the ideology of Siberian regionalism is addressed. The current article describes the contacts of Dostoevsky, the Petrashevtsy and the Siberians and reveals the peculiarity of Dostoevsky's creative work perception in this region.

The rough drafts of Naumov's article "From Childhood Memories (On the Death of Fyodor Dostoevsky)" are stored in the Tomsk archive of the Siberian writer; these materials show that Naumov primarily perceived Dostoevsky as a Siberian convict, a prisoner of Omsk prison. That is how Siberian regionalists perceived the famous Russian writer, and it was not a sort of a mistake, it was their position of principle.

This fact is particularly obvious in the creative work of N.M. Yadrintsev, one of the most distinguished journalists and, definitely, the leading literary critic in the Siberian region. His thoughts on Dostoevsky's creative works are found in his two literary criticism articles "Criminals Based on the Romantic and Naturalistic Schools" (1872) and "Dostoevsky in Siberia" (1897). The names of the articles are essential: Siberians were interested only in the "Siberian" Dostoevsky who illustrated the criminal world in prison and exile. In the article "Dostoevsky in Siberia", describing his meeting with Dostoevsky in 1876, Yadrintsev outlined only the writer's memories about exile, and, according to this article, exile is the only common theme for a Siberian man and Dostoevsky. Therefore, Yadrintsev considers Dostoevsky's The House of the Dead, in which the writer depicted the real world of Siberian exile (katorga), to be the best work of the writer. At the same time, he sharply criticized Crime and Punishment pointing out that the novel is false in terms of depicting a criminal and his inner world. It is significant that no other works of Dostoevsky are mentioned. The House of the Dead is the first Dostoevsky's work which is based on his concept of pochvennichestvo ('concept of the soil') shaped within the exile prison; this fact makes it possible to conclude about the impact of Dostoevsky's pochvennichestvo on Siberian regionalism.

G.N. Potanin, the spiritual leader of Siberian regionalism, fully agreed with Yadrintsev on the importance of The House of the Dead for the contemporary Russia. In addition, his Memoirs reveals the fact that the Petrashevtsy imprisoned in Siberia played a crucial role in shaping Siberian regionalism. Potanin claimed that it was acquaintance with M.V. Butashevich-Petrashevsky, Dostoevsky's friend within the circle, and S.F. Durov, the writer's companion in Omsk prison, and his short stories that changed his view on the life and political order of Russia. It was the beginning of Siberian regionalism. He was shocked by the tragic story of N.P. Grigor'ev who stood together with the other Petrashevtsy, M.V. Petrashevsky and N.A. Mombelly, as they were waiting for their death penalty enforcement surrounded by soldiers with their rifles on the ready, and went mad.

Personal meetings of Potanin, Yadrintsev and Naumov with Dostoevsky were few; however, the works of Siberian regionalists reveal the fact that Dostoevsky's exile and the Petrashevtsy' death penalty experiences, pochvennichestvo and the political views of the Petrashevtsy circle played a significant role in shaping Siberian regionalism. 


\section{References}

1. Department of Manuscripts and Book Monuments of Tomsk State University Rresearch Library. Archive Fund. (2008) Issue 7: Nikolay Ivanovich Naumov. List 14. Tomsk. (In Russian).

2. Novikova, E.G. (1996) Tomsk v zhizni N.I. Naumova: eskizy bez teney [Tomsk in the life of N.I. Naumov: sketches without shadows]. In: Kol'chuzhkin, E. (ed.) Russkie pisateli v Tomske [Russian writers in Tomsk]. Tomsk: Vodoley.

3. Popov, I.G. (ed.) (1963) Avtobiografiya, N.I. Naumova [Autobiography of N.I. Naumov]. Sibirskie ogni. 9. pp. 177-180.

4. Yanovskiy, N.N. (1986) Literaturnoe nasledstvo Sibiri [Literary heritage of Siberia]. Vol. 7. Novosibirsk: Zap.-Sib. kn. izd-vo.

5. Serebrennikov, N.V. (2002) Delo ob otdelenii Sibiri ot Rossii [A case on the separation of Siberia from Russia]. Tomsk: Tomsk State University.

6. Yanovskiy, N.N. (1983) Literaturnoe nasledstvo Sibiri [Literary heritage of Siberia]. Vol. 6. Novosibirsk: Zap.-Sib. kn. izd-vo.

7. Yadrintsev, N.M. (1872) Russkaya obshchina v tyur'me $i$ ssylke [The Russian community in prison and exile]. St. Petersburg: Tip. A. Morigerovskogo.

8. Yanovskiy, N.N. (1980) Literaturnoe nasledstvo Sibiri [Literary heritage of Siberia]. Vol. 5. Novosibirsk: Zap.-Sib. kn. izd-vo.

9. Zavalishin, I.I. (1862-1865) Opisanie Zapadnoy Sibiri: $v 3 t$. [Description of Western Siberia: In 3 vols]. Moscow: Tipografiya V. Gracheva i komp.

10. Viktorovich, V.A. (1991) Dostoevskiy i Vs. Krestovskiy [Dostoevsky and Vs. Krestovsky]. In: Fridlender, G.M. (ed.) Dostoevskiy: Materialy $i$ issledovaniya [Dostoevsky: Materials and research]. Vol. 9. Leningrad: Nauka.

11. Dostoevskiy, F.M. (1972-1990) Polnoe sobranie sochineniy: $v 30$ t. [Complete Works: In 30 vols]. Leningrad: Nauka.

12. Vladimirtsev, V.P. (2007) Dostoevskiy narodnyy. F.M. Dostoevskiy i russkaya etnologicheskaya kul'tura [The folk Dostoevsky. F.M. Dostoevsky and Russian ethnological culture]. Irkutsk: Irkutsk State University.

13. Obruchev, V.A. (1947) Grigoriy Nikolaevich Potanin: Zhizn' $i$ deyatel'nost' [Grigory N. Potanin: Life and work]. Moscow; Leningrad: USSR AS.

14. Yanovskiy, S.D. (1990) Vospominaniya o Dostoevskom [Memories of Dostoevsky]. In: Tyun'kin, K.I. (ed.) F.M. Dostoevskiy v vospominaniyakh sovremennikov: v 2 t. [F.M. Dostoevsky in the memories of his contemporaries: In 2 vols]. Moscow: Khudozhestvennaya literatura.

15. Gromyko, M.M. (1985) Sibirskie znakomye i druz'ya F.M. Dostoevskogo. 1850-1854 [Siberian acquaintances and friends of F.M. Dostoevsky. 1850-4]. Novosibirsk: Nauka.

16. L'vov, F.N. \& Butashevich-Petrashevskiy, M.V. (1984) [Zapiska o dele petrashevtsev] [[Note on the case of the Petrashevtsy]]. In: Volk, S.S. (ed.) Pervye russkie sotsialisty: Vospominaniya uchastnikov kruzhkov petrashevtsev v Peterburge [First Russian Socialists: Memories of members of the Petrashevtsy circles in Peterburg]. Leningrad: Lenizdat.

17. Vrangel', A.E. (1912) Vospominaniya o F.M. Dostoevskom v Sibiri 1854-56 gg. [Memories of F.M. Dostoevsky in Siberia, 1854-6]. St. Petersburg: Tip. A.S. Suvorina.

18. Novikova, E.G. (1998) G.N. Potanin in Tomsk: Philology, Siberia, East and Christianity. Vestnik Tomskogo gosudarstvennogo universiteta - Tomsk State University Journal. 266. pp. 27-33. (In Russian).

19. Alekseev, P.V. (2017) Chinese introduction to a Writer's Diary by Fyodor Dostoevsky. Vestnik Tomskogo gosudarstvennogo universiteta. Filologiya - Tomsk State University Journal of Philology. 49. pp. 98-112. (In Russian). DOI: 10.17223/19986645/49/7

20. Budanov, N.F. \& Fridlender, G.M. (eds) (1993) Letopis' zhizni i tvorchestva F.M. Dostoevskogo: $v \quad 3$ t. [Chronicle of the life and work of F.M. Dostoevsky: in 3]. St. Petersburg: Akademicheskiy proekt. 